come to depend on market relations rather than on patronage and kinship, and on their daughter's career instead of their own labor.

To sum up the main conclusion. Women without men are marginalized in varying degrees. They have lost their status as wife or daughter and their male provider and by consequence are often forced to trespass the boundaries of proper feminine behavior. Their marginality makes them fit for certain work. Women without men often assist in the rites of passage of birth, marriage, and death. In their occupations they mediate between impure and pure, earth and heaven, private and public space, the legal and the illegal market, and between feminity and masculinity. Many of these activities make them even more marginal. They are avoided when their services are not needed. because they handle taboo substances such as body residues, corpses, spirits, hymens, afterbirth, or contraband.

On the other hand, they exploit their marginality and stress their stigma in order to maintain a monopoly over their activities. They manipulate symbols of shame to increase their income. They accentuate the cultural opposites to make their work as mediators meaningful and necessary. While bridging the opposites, they will at the same time work to maintain the gap between them. In their marginality they break gender norms, but by being unfeminine, they help to set the boundaries of feminity.

Women without men do indeed derive power from their strategic position as mediators. They may be marginal, but they are at the same time the pivots of the cultural order. They gain power from the monopoly they have over functions that others are unable or unwilling to perform. Although they lack some of the power resources of married women, they have more access to the labour market and money, extra-domestic organization and information. Because of their extra power they are seen as disturbers of the social order and gender hierarchy. But despite their potential for personal power, the influence of women without men on the overall gender hierarchy is limited. In fact, they often help to maintain the status quo because their positions depend on the persistence of power differentials between the genders. Moreover, the stigma attached to women without men limits their function as paragon in an emancipatory process. More can be expected of the younger generation, the daughters of widows and divorcees, whose wages are rather based on education than on shame.

\title{
BOOK FUND IN MEMORIAM PETER KILBURN
}

IN APRIL 1986, shortly after the U.S. attack on Libya, and apparently in direct reprisal for it, a U.S. citizen, Peter Kilburn, was murdered in Lebanon. He had been taken hostage sixteen months previously and, since he was an invalid, it was assumed, at least by some of his friends, that he had not survived long in captivity without his medicines. The news of his death came as a double blow to his family and friends. 
Peter Kilburn was a librarian at the American University of Beirut. $\mathrm{He}$ was well known to faculty and students there, as well as to scholars of Near Eastern Studies who used the AUB library facilities, for his professional expertise and his personal warmth and generosity. He was constantly broke, for over the years he had helped all sorts of refugees in Beirut, and in some cases had personally financed their education. Prior to coming to Beirut in 1963 he had lived in Turkey and Morocco. Peter Kilburn loved the Middle East in general and Lebanon in particular; his life was devoted to the cause of better understanding between Westerners and Arabs.

Friends have established a Book Fund in his name at the School of International Training in Brattleboro, Vermont, to further the understanding of the Near East in the United States. The fund will purchase books on the Near East to improve and expand the school's collection, which before the establishment of the fund was limited and out of date. Books are marked with a plate inscribed IN MEMORIAM PETER C. KILBURN and also bear a phrase in Arabic expressing his deepest wish: in Lebanon).

(Peace

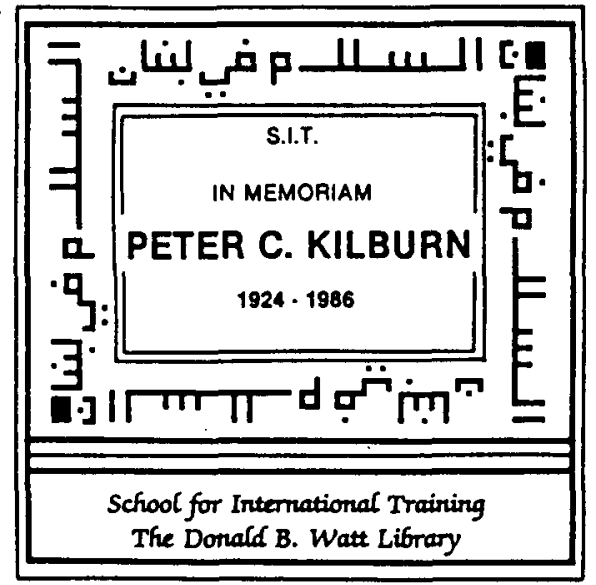

Response to announcements of the book fund has been heartening. Friends of Peter Kilburn and scholars who knew him, as well as people who did not know him personally but who were saddened by his death or ashamed because of the way he died, have already shown their concern. The board of directors of MESA has agreed to donate MESA publications to the fund and to sponsor this announcement. If you would like to contribute to the fund you may either send a donation or any publications or books to: Ms. Shirley Capron, Librarian, School of International Training, Brattleboro, Vermont 05301.

RICHARD H. DEWEY, Hudson, N.H. DaVID A. KING, Frankfurt, Federal Republic of Germany 